\title{
Validation of the Lithuanian Version of Moral Competence Test and Application of KMDD in Language Teaching / Learning Process at Vilnius University, Lithuania
}

\author{
Roma Kriaučiūniene \\ (Vilnius University; Lithuania; roma.kriauciuniene@flf.vu.lt) \\ ORCID: 0000-0002-9356-1098 \\ Georg Lind \\ (University of Konstanz; Germany; georg.lind@uni-konstanz.de) \\ ORCID: 0000-0002-2235-5465
}

\begin{abstract}
The findings obtained by G. Lind using his original research instrument - the Moral Competence Test - suggest that universities lack the capacity to foster students' moral competence development. The MCT has been translated into 39 languages, all of which have gone through the necessary validation procedure. The article reports on the MCT validation study for the 40th language, namely Lithuanian. The research sample consisted of 526 students of English/German/French languages, future foreign language teachers, in the 1 st to 4 th years of study at two universities in Lithuania: the former Vilnius Pedagogical University and the Vilnius University. The majority of the respondents demonstrated low or medium level of moral competence. On the basis of this cross-sectional study (2019-2020), the MCT for Lithuanian has been successfully validated and certified. In the following article, we present and discuss all the validation criteria and revisit the theoretical background of MCT. We also argue for educating students in moral competence and evaluating the effects of moral competence promotion in academic contexts.
\end{abstract}

Keywords: Moral competence; moral competence development; Moral Competence Test in Lithuanian version; MCT; validation study; KMDD; Konstanz Method of Dilemma Discussion; English language teaching/learning process.

\section{Objectives}

The following paper reports on the validation and certification of the Moral Competence Test (MCT) for the Lithuanian language. Moral competence is defined by Lind (2019) as the ability to resolve problems and conflicts on the basis of moral principles, merely by thinking and discussion, instead of through the use of violence, deceit or by submitting to an authority. In particular, it is defined as the ability to evaluate arguments put forward by others in terms of their moral quality rather than in terms of opinion agreement. This is the very prerequisite for living in a democratic society.

The MCT is a behavioral experiment which makes moral competence visible. It is 
based on the psychological dual-aspect-theory of moral behavior, but does not invoke any statistical assumptions as other psychological tests do. In order answer the question of whether the test measures what it is supposed to measure, the MCT was submitted (a) to several reviews by experts of moral psychology, and (b) to three rigorous empirical tests. These three tests were also used to check the cross-cultural validity of the Lithuanian version of the MCT. In addition, we report the findings from a study on the significance of moral competence for a teacher's ability to foster students' moral competence.

The validation study was conducted with students $(N=526)$ of Vilnius University in 2020. The Lithuanian MCT conforms almost perfectly with the first two criteria. Because of this nearly perfect confirmation, the correlations were so high that the third criterion could not be tested.

Moreover, the findings indicate the distribution of moral competence in Lithuanian students training to be language teachers, in terms of their development during their university courses.

\section{Theoretical Background}

Lind $(1978 ; 1982 ; 2019)$ created the MCT in order to make moral competence visible. It is a behavior experiment with a multivariate orthogonal design, as Egon Brunswik (1955) had suggested. This means that the MCT is not a "test" in the sense of psychology tests, but it is an $n=1$ experiment, operationalized as a questionnaire. Because of this experimental design, the participants' pattern of responses lets us directly see the properties of their moral competence without the aid of certain statistical models, as is the case with classical psychological tests. As a result, the criteria of classical tests do not apply. The moral consistency of participants' responses is used as an indicator for their moral competence, not as a sign of test stability. As the MCT has not been changed since its inception in 1977 (Lind 1978, 2013), it can be considered stable and reliable.

The MCT's validity is checked using four well established psychological findings about the nature of moral judgment behavior:

1) The six types of moral orientations, as defined by Kohlberg (1984), form a universal preference hierarchy;

2) As Piaget (1976) concluded from his observations, moral orientations and moral competence are "parallel", that is, they correlate in highly predictable manner;

3) Neighboring types of moral orientations correlate higher with one another than more "distant" types (simplex structure); and

4) Moral competence cannot be faked upward, as attitudes and orientations can. These psychological (instead of solely statistical-formal) validity criteria provide much more rigorous criteria for the validity of experimental designs than the conventional statistical criteria used in test psychology. These findings serve as criteria of the MCT's psychological validity. The first three are obligatory for testing the validity of new test 
versions and translations of the MCT.

These three criteria are very rigorous. They allow us to detect even small errors. Rigorous means that the a priori probability of confirming these criteria by chance is extremely small, and, therefore, their confirmation is extremely informative (Karl Popper). For example, the a priori probability of confirming the statistical hypotheses that two groups of people differ regarding some trait, is almost $100 \%$, if the groups are very large. In contrast, the a priori probability for a single individual's preference hierarchy of six moral orientations is only $1 / 6 !=1 / 720=0.0014$ or $0.14 \%$. When we test this validity hypothesis with many individuals, the probability of a confirmation by chance is extremely small.

Although these validity criteria are very rigorous, they have been supported very well so far by all studies. Hence, we can safely say that the MCT is psychologically valid, i.e., it can truly make moral competence visible.

\section{Method}

The Moral Competence Test (standard version) consists of two dilemma stories. Each story is followed by six arguments in favor of the protagonist's decision, and six against it. Each argument represents of the six types of moral orientation defined by Kohlberg (1984). The first author of this paper has translated the MCT from English into the Lithuanian language. Participants were recruited and surveyed randomly. Participation was voluntary and anonymous, occurring during their class hours. Data were collected for several weeks. The sample consisted of 654 participants, 604 females and 50 males, aged 19 to 23, only Lithuanian speakers, representing various fields of study. The central C-score was computed according to the algorithm developed by Lind.

Here is one of the dilemma stories and some sample arguments:

\section{MORALINĖS KOMPETENCIJOS TESTAS}

Prašome atidžiai perskaityti šias dvi dilemas. Ivertinkite pasiūlytus jų sprendimo variantus ir prie kiekvieno iš jų pažymėkite, ar Jūs sutinkate ar nesutinkate su tokiu sprendimu apibraukdami skaičiu nuo $-4 \mathrm{iki}+4$.

\section{Darbininku}

Dèl atrodytų nepagrịstų atleidimų iš darbo kai kurie gamyklos darbininkai įtaria, kad vadovai, naudodamiesi vidinio telefono ryšiu, slapta klausosi savo darbuotoju pokalbių ir šią informaciją naudoja prieš juos. Vadovai oficialiai ir primygtinai neigia šiuos kaltinimus. Profesinè sąunga teigia besiimsianti priemonių prieš kompanija tik tuo atveju, kai šie itarinejjimai bus pagrįsti tikrais įkalčiais. Tuomet darbininkai įsilaužia į administracijos patalpas ir paima įrašus, įrodančius, jog kaltinimai dèl slapto klausymosi yra pagristi.

Ar Jūs pritartumėte ar
nepritartumète darbininkuc
elgesiui?

$\begin{array}{lllllll}-3 & -2 & -1 & 0 & +1 & +2 & +3\end{array}$




\begin{tabular}{|c|c|}
\hline $\begin{array}{l}\text { Ar pritartumète šiems argumentams palankiai } \\
\text { vertinantiems dviejų darbininkų elgesį? Tarkime, } \\
\text { kas nors tvirtintų, jog jie buvo teisūs... }\end{array}$ & $\begin{array}{l}\text { Visiškai } \\
\text { nepritariu }\end{array}$ \\
\hline 1. nes jie nepadarė jokios žalos gamyklai. & $\begin{array}{llllllll}-4 & -3 & -2 & -1 & 0 & +1+2+3 & +4\end{array}$ \\
\hline $\begin{array}{l}\text { 2. nes įmonè nepaisė įstatymų, vadinasi, dviejų } \\
\text { darbininkų elgesys buvo leistinas teisingumui ir } \\
\text { tvarkai atstatyti. }\end{array}$ & $\begin{array}{ccccccc}-4 & -3 & -2 & -1 & 0 & +1+2 & +3 \\
+\end{array}$ \\
\hline $\begin{array}{l}\text { 3. nes dauguma darbininkų pritartų jų poelgiui ir } \\
\text { dauguma tuo džiaugtųsi. }\end{array}$ & $\begin{array}{llllllll}-4 & -3 & -2 & -1 & 0 & +1+2 & +3 & +4\end{array}$ \\
\hline $\begin{array}{l}\text { 4. nes pasitikėjimas žmonèmis ir asmeninis orumas } \\
\text { reiškia daugiau negu įmonės gerovè. }\end{array}$ & $\begin{array}{cccccccc}-4 & -3 & -2 & -1 & 0 & +1+2 & +3 & +4\end{array}$ \\
\hline $\begin{array}{l}\text { 5. nes įmonè pati pirma pažeidè teisingumą, tai } \\
\text { dviejų darbuotojų įsibrovimą i administraciją galima } \\
\text { pateisinti. }\end{array}$ & $\begin{array}{lllllll}-4 & -3 & -2 & -1 & 0 & +1+2 & +3+4\end{array}$ \\
\hline $\begin{array}{l}\text { 6. nes abu darbininkai nematė jokių juridinių } \\
\text { priemonių, kaip atskleisti įmonès piktnaudžiavimą ir } \\
\text { todèl pasirinko, kas jų manymu teisinga. }\end{array}$ & 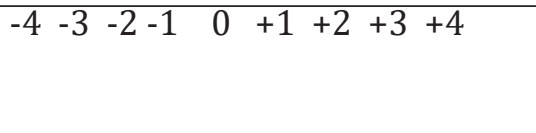 \\
\hline $\begin{array}{l}\text { Ar pritartumėte šiems argumentams nepalankiai } \\
\text { vertinantiems dviejų darbininkụ elgesị? Tarkime, } \\
\text { kas nors tvirtintų, jog jie buvo neteisūs... }\end{array}$ & $\begin{array}{l}\text { Visiškai } \\
\text { nepritariu }\end{array}$ \\
\hline $\begin{array}{l}\text { 7. nes ịstatymams ir tvarkai visuomenèje iškiltų } \\
\text { grèsmè, jeigu visi elgtųsi taip, kaip tie du darbinil }\end{array}$ & $\begin{array}{cccccccc}-4 & -3 & -2 & -1 & 0 & +1+2 & +3 & +4\end{array}$ \\
\hline
\end{tabular}

(Excerpt of the Moral Competence Test in Lithuanian translation; the full test is available from the second author: Georg.Lind@moralcompetence.net).

\section{Results Regarding the Validity of the Lithuanian MCT}

The findings confirm the first two hypothesis very well.

The criterion of "preference hierarchy". The six types of moral orientations are preferred and rejected in the way that moral psychological theory predicts: The moral orientation types 5 and 6 are the most preferred, and and types 2 and 1 are the most rejected (Figure 1). There is only a slight inversion of preference order among the orientations types 1 and 2. So far, this has been found in all other studies (Lind 2002, 2013).

The criterion of "affective-cognitive parallelism". The six types of moral orientations correlate with moral competence (the C-score of the MCT) exactly in the way that was predicted on the basis of Piaget's notion: The type 6 moral orientation correlates the highest with moral competence, and type 1 the lowest. In other words, the higher the participants' moral competence, the more clearly they prefer better moral orientations than less adequate ones. 


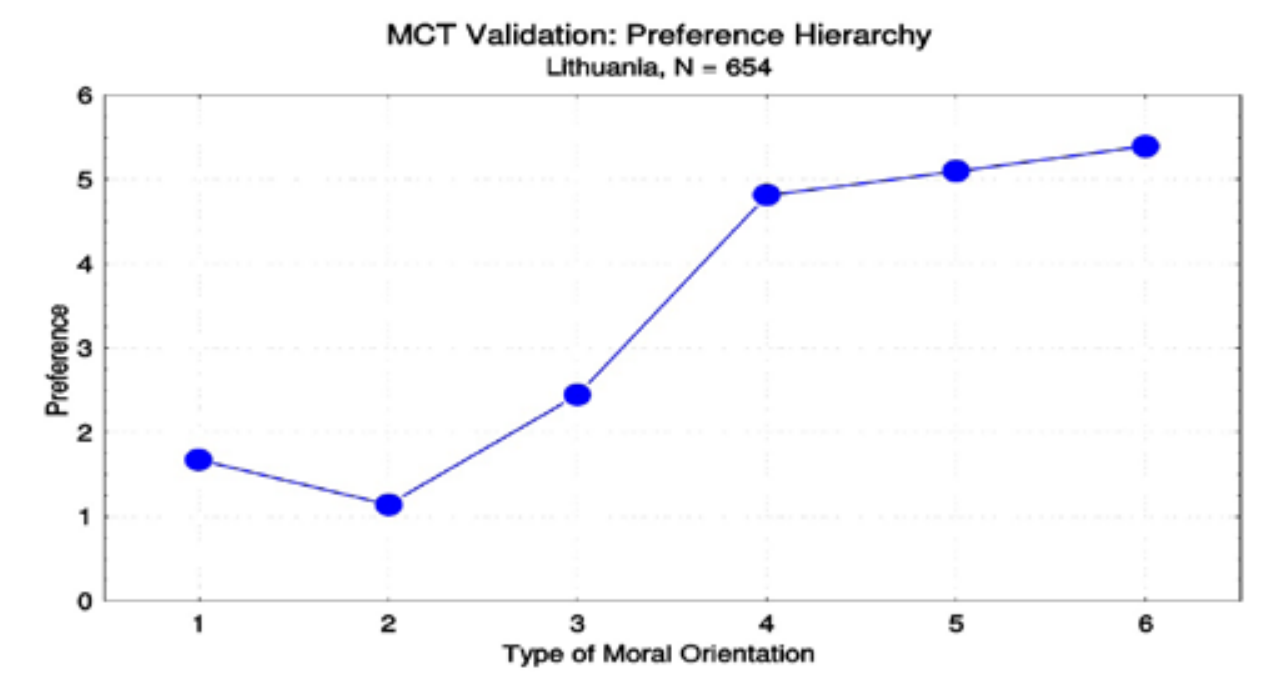

Figure 1: Validation criterion 1: Preference hierarchy (moral orientations 1 to 6, according to Kohlberg). This criterion was fully met.

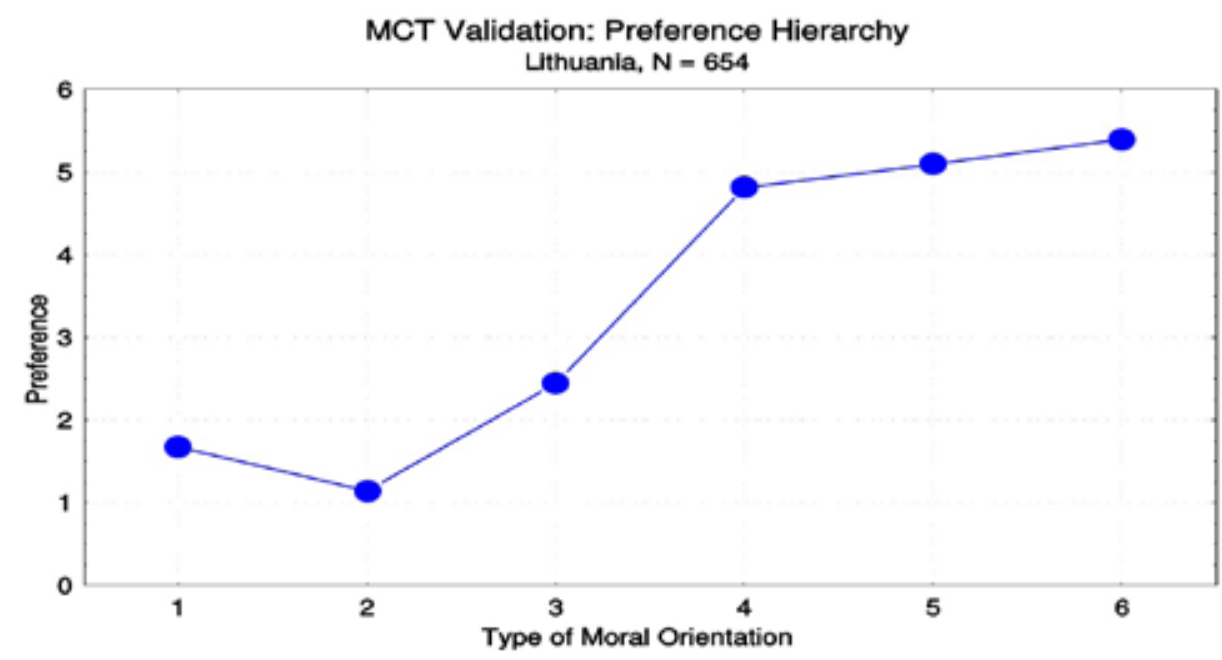

Figure 2: Validation criterion 2: Affective-cognitive parallelism. This criterion was fully met.

The third validity hypothesis (simplex quasi-structure) could not be tested in this data set because the first two critera fit extraordinarly well. Because of this, all six types of moral orientation correlated almost perfectly with one-another. This does not imply that the third criterion of validity is falsified, but only means that it cannot be tested with this set of data. The fourth criterion is optional, because it is very laborious.

In sum, like the original MCT, the Lithuanian translation is highly valid. That is, it allows us to measure two distinct aspects of moral behavior, moral orientations and moral competence, simultaneously and validly (1982, 2002, 2019). Hence there is no need anymore to rely on subjective methods like clinical interviews (Lind 1989). The MCT makes moral competence visible without imposing statistical models on the data. Statistics are used only to translate the graphical results into numerical results (C-score) so that the findings can be used for studying research questions. 


\section{The Relevance of Moral Competence for a Teachers' Ability to Foster Moral Competence}

Many research findings suggest that universities fail to foster students' moral competence (Lind 2000, 2001, 2002, 2013). Therefore, we tested the moral competence of 526 students of English, German and French languages, future foreign language teachers, in the $1^{\text {st }}-4^{\text {th }}$ years of their studies at two universities in Lithuania (the former Vilnius Pedagogical University and Vilnius University). All students showed, as seen in Figure 1 above, high moral orientations. They preferred principled moral reasoning (Type 5 and 6) over legalistic or conformity morality, and these over pre-conventional moral orientations.

However, their average moral competence was rather low. Many lack the ability to apply their moral orientations to their behavior.

\section{Distribution of Moral Competence Among Lithuanian Language Teacher Students \\ $N=654$}

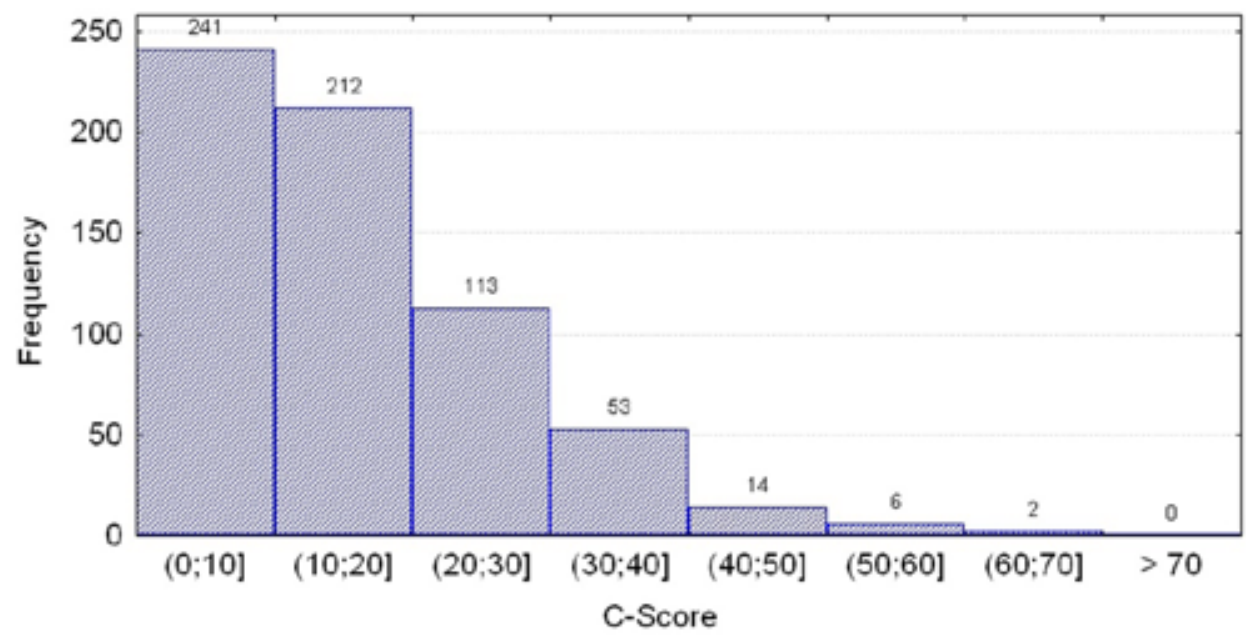

Figure 3: Distribution of moral competence.

Some researchers (Wood 2007; Thornberg 2008; Brimi 2009; Hoekema 2011; Kiss \& Euben 2011) argue that fostering students' moral development should be given a high priority by universities. In spite of this, universities seem to have little impact on students' moral competence development. As Figure 5 shows, students' moral competence does not seem to be affected at all by their university studies. 


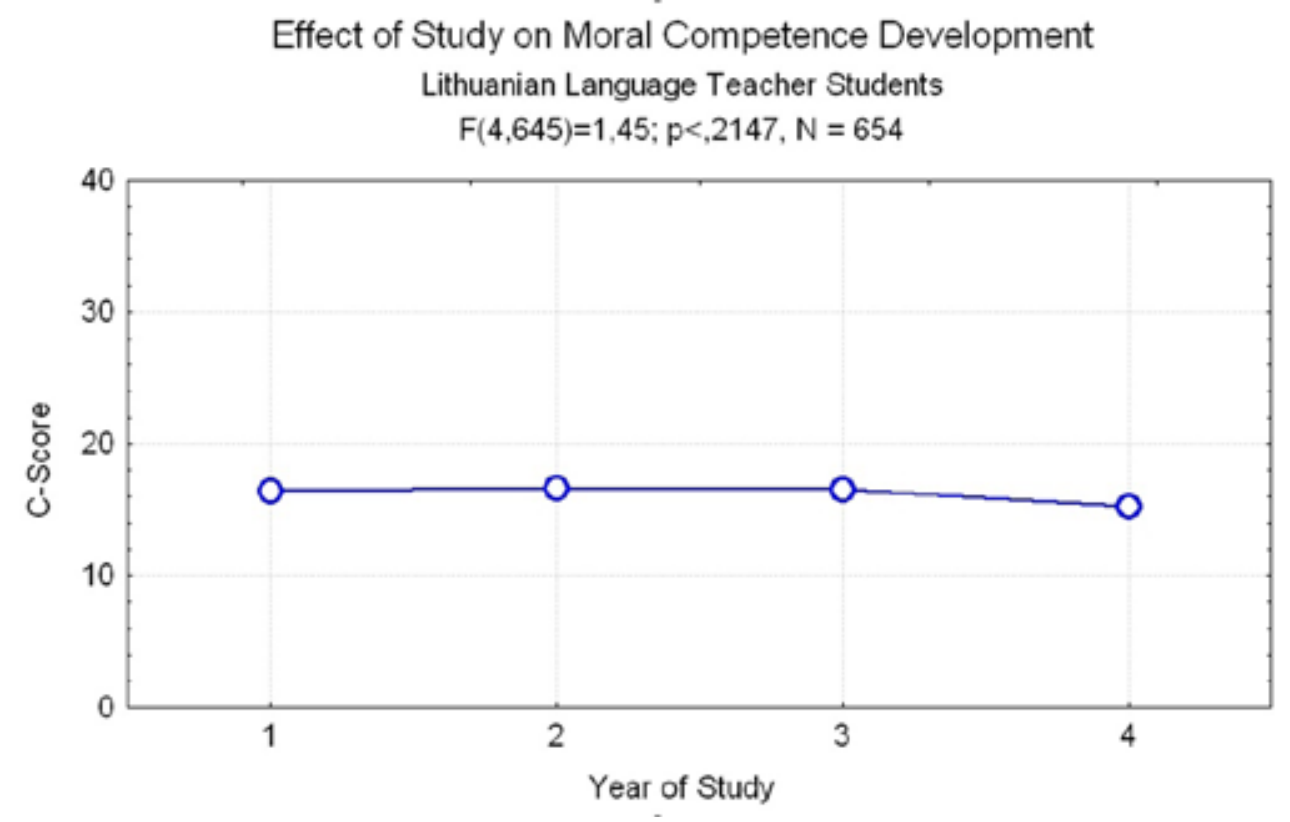

Figure 4: Changes in university students' moral competence during their studies (cross-sectional study).

How could that be changed, ask E. Kiss and J. P. Euben (2011)? Moral competence research suggests that this can be done in two ways. First, students' moral competence can improve when their university gives them at least some opportunities for responsibility-taking and guided reflection (Lind 2000, 2002, 2013, Schillinger 2006). Second, students' moral competence can be promoted purposefully by using the Konstanz Method of Dilemma-Discussion (KMDD; Lind 2019). We applied the KMDD in the teaching and learning process of the English language at Vilnius University and the KMDD effect upon the learners' moral competence C-score following the pre-testing and post-testing procedure by MCT was measured. The intervention was carried out in 2019 during the English language course English for Academic Purposes and Research with $1^{\text {st }}$ year students of the study program Childhood Pedagogy (30) at the beginning of the semester. The participants were tested before and after the interventions using the MCT. The intervention produced an increase of $1.8 \mathrm{C}$-points. This is small, because the KMDDteacher was not fully trained and certified. But it is encouraging as the control group's C-score did not move at all.

\section{Conclusion}

The Lithuanian version of the Moral Competence Test (MCT) is highly valid. It is the $40^{\text {th }}$ language version of the MCT. Most have also been validated. The validation of some versions is still pending (see http://moralcomptence.net).

The MCT makes moral competence visible. Its scores show how effective or ineffective our schools and universities are in terms of fostering students' moral competence.

Teachers of secondary and higher education can use it to see how effective they are at fostering the moral competence of their students, and whether they need additional training to become more effective. 


\section{References:}

Brimi H. 2009. "Academic Instructors or Moral Guides? Moral Education in America and the Teacher's Dilemma," Clearing House 82(3):125-130. Academic Search Complete, EBSCOhost, viewed 5 January 2015.

Hoekema D. 2011. "Is There an Ethicist in the House? How Can We Tell?," in E. Kiss \& J. P. Euben (Eds.), Debating Moral Education: Rethinking the Role of the Modern University. Durham: Duke University Press.

Kiss E., \& Euben J. P. (Eds.) 2011. Debating Moral Education: Rethinking the Role of the Modern University. Durham: Duke University Press. Published online: 12 October 2011. Springer Science+Business Media B.V.

Kohlberg L. 1984. The Psychology of Moral Development. Vol. 2: Essays on Moral Development. San Francisco: Harper \& Row.

Lind G. 1978. „Wie misst man moralisches Urteil? Probleme und alternative Möglichkeiten der Messung eines komplexen Konstrukts," in G. Portele (Ed.), Sozialisation und Moral (pp. 171-201). Weinheim: Beltz,

Lind G. 1982. "Experimental Questionnaires: A New Approach to Personality Research," in A. Kossakowski \& K. Obuchowski (Eds.), Progress in Psychology of Personality (pp. 132-144). Amsterdam: North-Holland.

Lind G. 1989. "Measuring Moral Judgment: A Review of The Measurement of Moral Judgment by Anne Colby and Lawrence Kohlberg," Human Development 32:388-397.

Lind G. 2000. "The Importance of Role-taking Opportunities for Self-sustaining Moral Development," Journal of Research in Education 10(1):9-15.

Lind G. 2001. "From Practice to Theory. Turning Teacher Education on Its Feet." http:// moralcompetence.net/b-liste.htm

Lind G. 2002. Ist Moral lehrbar? Ergebnisse der modernen moralpsychologischen Forschung. $2^{\text {nd }}$ Edition. Berlin: Logos Verlag.

Lind G. 2013. "Favorable Learning Environments for Moral Competence Development A Multiple Intervention Study with Nearly 3.000 Students in a Higher Education Context," International Journal of University Teaching and Faculty Development 4(4):173-192.

Lind G. 2010. "Growth and Regression in Cognitive-moral Development in Young University Students," in C. G. Harding (Ed.), Moral Dilemmas and Ethical Reasoning (pp. 99-114). New York: Routledge.

Lind G. 2019. How to Teach Morality. New: Discussion Theater. Berlin: Logos Publishers.

Piaget J. 1976. "The Affective Unconscious and the Cognitive Unconscious," in B. Inhelder \& H. H. Chipman (Eds.), Piaget and His School (pp. 63-71). New York: Springer.

Schillinger M. 2006. Learning Environments and Moral Development: How University Education Fosters Moral Judgment Competence in Brazil and two German-speaking Countries. Aachen: Shaker Verlag. 
Thornberg R. 2008. "The Lack of Professional Knowledge in Values Education, Teaching and Teacher Education," International Journal of Research and Studies 24(7):17911798. URL: http://dx.doi.org/10.1016/j.tate.2008.04.004. Copyright: Elsevier Science B.V., Amsterdam, http://www.elsevier.com (last viewed on 20 Dec 2020). 